\title{
33. THE EQUATORIAL PACIFIC HIGH-PRODUCTIVITY BELT: ELEMENTS FOR A SYNTHESIS OF DEEP SEA DRILLING PROJECT LEG 85 RESULTS ${ }^{1}$
}

\author{
F. Theyer, Department of Geological Sciences, University of Southern California \\ L. A. Mayer, Department of Oceanography, Dalhousie University, Halifax, Nova Scotia \\ J. A. Barron, U.S. Geological Survey, Menlo Park \\ and \\ E. Thomas, Scripps Institution of Oceanography, University of California, San Diego ${ }^{2}$
}

\begin{abstract}
Leg 85 of the Deep Sea Drilling Project operated in the eastern central Pacific in the region of the equatorial highproductivity belt. We recovered uppermost Eocene to Quaternary reference sections amenable to fine-scale stratigraphic and paleoceanographic research, using primarily the hydraulic piston corer. Four sites (572 to 575) were drilled along an east-west (about 114 to $133^{\circ} \mathrm{W}$ ) and north-south (about 0.5 to $6^{\circ} \mathrm{N}$ ) transect across the equatorial belt.

At Site 572 an apparently complete lower middle Miocene to Quaternary sequence was recovered: the sediment sections are dominantly siliceous-calcareous oozes and chalks, and sediment accumulation rates were high ( 30 to $60 \mathrm{~m} /$ m.y.). Sediments at Sites 573 to 575 are similar and dominated by siliceous and calcareous oozes and chalks. Sediment accumulation rates at Site 573 were generally between 10 and $35 \mathrm{~m} / \mathrm{m} . \mathrm{y}$. The upper Eocene to Quaternary sequence is punctuated by seven hiatuses. At Site 574 a nearly complete upper Eocene to Quaternary sequence was retrieved, including a continuous Eocene to Oligocene transition. At Site 575 a lower Miocene to Quaternary section was cored. The lower to middle Miocene section is characterized by high, constant carbonate contents and sediment accumulation rates of about $20 \mathrm{~m} / \mathrm{m}$.y.; the top of the recovered section contains two hiatuses and has accumulated at rates of less than 10 $\mathrm{m} / \mathrm{m} . \mathrm{y}$.

Except for thin, basal metalliferous layers, compositional changes in Leg 85 sediments result from shifts in the relative abundances of the biogenic siliceous or calcareous components. Leg 85 sites subsided and migrated at about $0.3 \mathrm{~cm} / \mathrm{yr}$., from about $3000 \mathrm{~m}$ in the eastern Pacific, south of the equator, to deeper ( 4000 to $4600 \mathrm{~m}$ ), more western locations at or north of the equator. The sedimentary sequences recorded regional changes in productivity (biogenic sedimentation), dissolution, and erosion associated with the equatorial belt, as well as global paleoceanographic events. The most striking regional trend is an east-west decreasing gradient in deposition of biogenic silica, prevailing from middle Miocene to Recent, which mirrors present-day surface-water productivity. A less pronounced middle Miocene to Recent latitudinal trend in deposition appears to be the result of enhanced carbonate solution to the north. The effects of deposition in the equatorial high-productivity belt have not changed since the early Miocene. Below the middle/upper Miocene boundary, the sediments have a relatively constant high carbonate content, whereas above, carbonate percentages are highly variable. The changeover level is generally marked by a hiatus and significant changes in physical, chemical, and magnetic properties of the sediments.

Results of Leg 85 contributed to advances in the four elements needed for an eventual paleoceanographic synthesis: (1) a high-resolution, multidisciplinary, and integrated datum-plane scheme and time scale, with an overall resolution of 0.13 to $0.38 \mathrm{~m}$.y., was established; (2) a system of correlatable acoustic reflectors was delineated over vast distances, and these reflectors were calibrated against age and physical and chemical properties at Sites 574 ; (3) a fine-scale geochemical (stable isotope and $\mathrm{CaCO}_{3}$ ) and micropaleontological climatic reconstruction was developed (discontinuously) from Oligocene to Pleistocene; and (4) broadly correlatable hiatuses (NH, PH), defined by previous work, were recognized at Sites 573 to 575 .

The interval from 8 to $9 \mathrm{Ma}$ serves to outline how integration of the foregoing elements could lead to a future synthesis. In the central basin of the equatorial Pacific, the interval from 8 to $9 \mathrm{Ma}$ is marked by a hiatus (NH5) in siliceous clays. A correlative hiatus occurs in carbonate oozes of the equatorial region and in the northeastern Pacific rim, and may be correlated with the "Purple" equatorial Pacific reflector. The interval is characterized globally by a regression, by strong carbonate dissolution, and by isotopic and micropaleontological evidence of marked cooling. Further study of these paleoceanographic phenomena in a variety of depositional environments will lead to an understanding of their relationships and functioning.
\end{abstract}

\section{INTRODUCTION}

The central equatorial Pacific, and especially its eastern central high-productivity belt, is a region of fundamental importance to marine geology. Beginning with

\footnotetext{
${ }^{1}$ Mayer, L., Theyer, F., et al., Init. Repts. DSDP, 85: Washington (U.S. Govt. Printing Office).

2 Addresses: (Theyer) Department of Geological Sciences, University of Southern California, University Park, Los Angeles, CA 90089; (Mayer) Dalhousie University, Halifax, Nova Scotia, Canada B3H 4JI; (Barron) U.S. Geological Survey, 345 Middlefield Rd., Menlo Park, CA 94025; (Thomas, present address) Lamont-Doherty Geological Observatory, CoPark, CA 94025: (Thomas, present add
}

Murray and Renard (1891), many of the pioneering marine geological deep-sea investigations (i.e., Arrhenius, 1952; Bramlette, 1961; Riedel and Funnel, 1964; Peterson, 1966; Hays et al., 1969, 1972; Berger, 1973; Winterer, 1973) concentrated on this area, where four previous DSDP legs $(5,8,9,16)$ operated (Fig. 1). These previous efforts culminated in the marine geological and paleoceanographic synthesis of the equatorial Pacific by van Andel et al. (1975). Characterized by intensive activity and rapid advances, this initial phase of central $\mathrm{Pa}$ cific research was instrumental in establishing global Tertiary tropical biostratigraphy and chronology, in shap- 


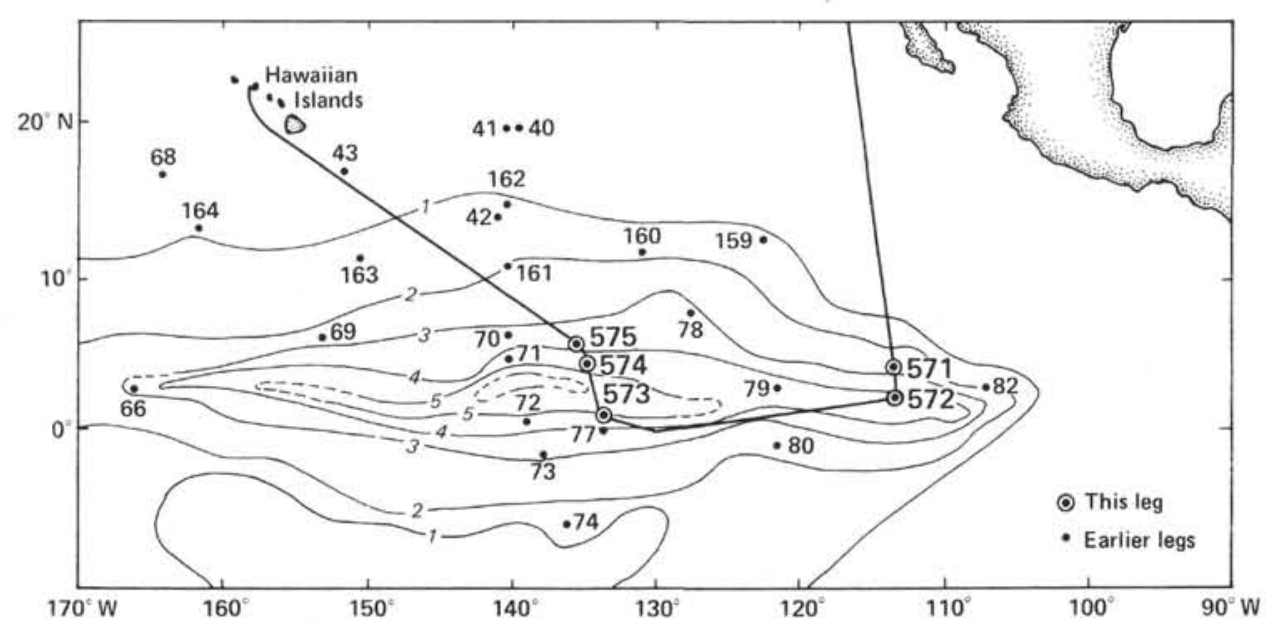

Figure 1. Cruise track and DSDP Leg 85 site locations in relation to acoustic sediment thickness (tenths of second, two-way traveltime) and previous DSDP operations (Legs 5, 8, 9, 16). Acoustic stratigraphy from Ewing et al. (1968).

ing our broad understanding of paleoceanography, and in developing tectonic reconstructions of the Pacific. Publication of the synthesis by van Andel et al. (1975) was followed by a leveling off in regional research activity. The Glomar Challenger did not return to the area until 1982 , and paleoceanography began to focus primarily on elucidating the fine details of latest Tertiary and Quaternary records. This fine-scale work requires expanded sedimentary sequences amenable to high-resolution sampling. Such sequences were available only in relatively short (5- to $15-\mathrm{m}$ ) conventional piston cores; rotary-drilled sections from previous DSDP central Pacific legs were too disturbed in the upper, generally unconsolidated 100 to $300 \mathrm{~m}$ (which comprises much of the Neogene) to be useful for high-resolution research.

With the development of the hydraulic piston corer (HPC) by Storms and Serocki (Prell, Gardner, et al., 1982) came the ability for the Glomar Challenger to recover undisturbed cores from the upper part of the sedimentary record and thus to begin a high-resolution phase in studies of the central equatorial Pacific. DSDP Leg 85 was designed to recover undisturbed and continuous equatorial Pacific Tertiary and Quaternary reference sections, using a modified, variable-length HPC (VLHPC; see Introduction, this volume).

Five sites were chosen by the JOIDES Ocean Paleoenvironment Panel (Fig. 1). Two sites (571 and 572) are in the eastern Pacific, whereas three of the sites (573, 574, and 575) form a north-south line, along approximately $133^{\circ} \mathrm{W}$, across the equatorial high-productivity zone. We piston cored each site twice to ensure complete recovery of the sedimentary sequences; then followed rotary drilling to basement (in the stiffer sediments below the reach of the HPC) at Sites 572 to 574 . Basement is Miocene at Sites 571 and 572 (Site 572 repeats Site 81 of Leg 9; Hays et al., 1972) and uppermost Eocene at Sites 573 to 575 (Fig. 2).

Leg 85 was expected to expand significantly the scope of earlier equatorial Pacific studies by providing the sediments and data necessary to carry out fine-scale stratigraphic and paleoceanographic research. The detail and breadth of the results in the present volume show that this expectation was met. In this preliminary synthesis we present the salient results of work completed for this volume and discuss the scientific elements uncovered by Leg 85 that seem essential to an understanding of this region.

\section{GEOLOGICAL AND OCEANOGRAPHIC SETTING}

The interplay of three fundamental processes has shaped the depositional history of the central and eastern equatorial Pacific. These processes are the tectonism of the spreading seafloor, biological productivity in the overlying waters, and changes in oceanographic conditions, both on the surface and near the seafloor (van Andel et al., 1975).

The dominant tectonic feature of the region is the East Pacific Rise (Fig. 2), at which new crust is generated at rates of 8 to $20 \mathrm{~cm} / \mathrm{yr}$., and which delineates four major plates, the Pacific (on which all Leg 85 sites lie), North American, Cocos, and Nazca (Sclater et al., 1971; Anderson and Sclater, 1972; Herron, 1972). During the last $50 \mathrm{~m}$.y., new Pacific crust has been continuously moving (and rotating) northwestward (Francheteau et al., 1970), spreading away from the East Pacific Rise and subsiding from an initial depth of about $3000 \mathrm{~m}$ (Sclater et al., 1971). This motion has two crucial results. First, it continuously alters the relationship between the equatorial high-productivity belt (surface waters) and its depositional expression on the seafloor (Fig. 1). And, second, the subsidence with age resulting from cooling of the young crust exposes solution-susceptible calcium carbonate to corrosive waters below or near the lysocline (Berger, 1973; Berger and Winterer, 1974).

Superimposed on this tectonic framework, biological productivity plays its role. The equatorial current system and its associated zones of upwelling create one of the Earth's most fertile planktonic belts along the equator, especially in the eastern Pacific (Austin, 1960; Defant, 1961; Reid, 1962; Lisitsin, 1970; Koblentz-Mishke et al., 1970). The sediments associated with this belt are 


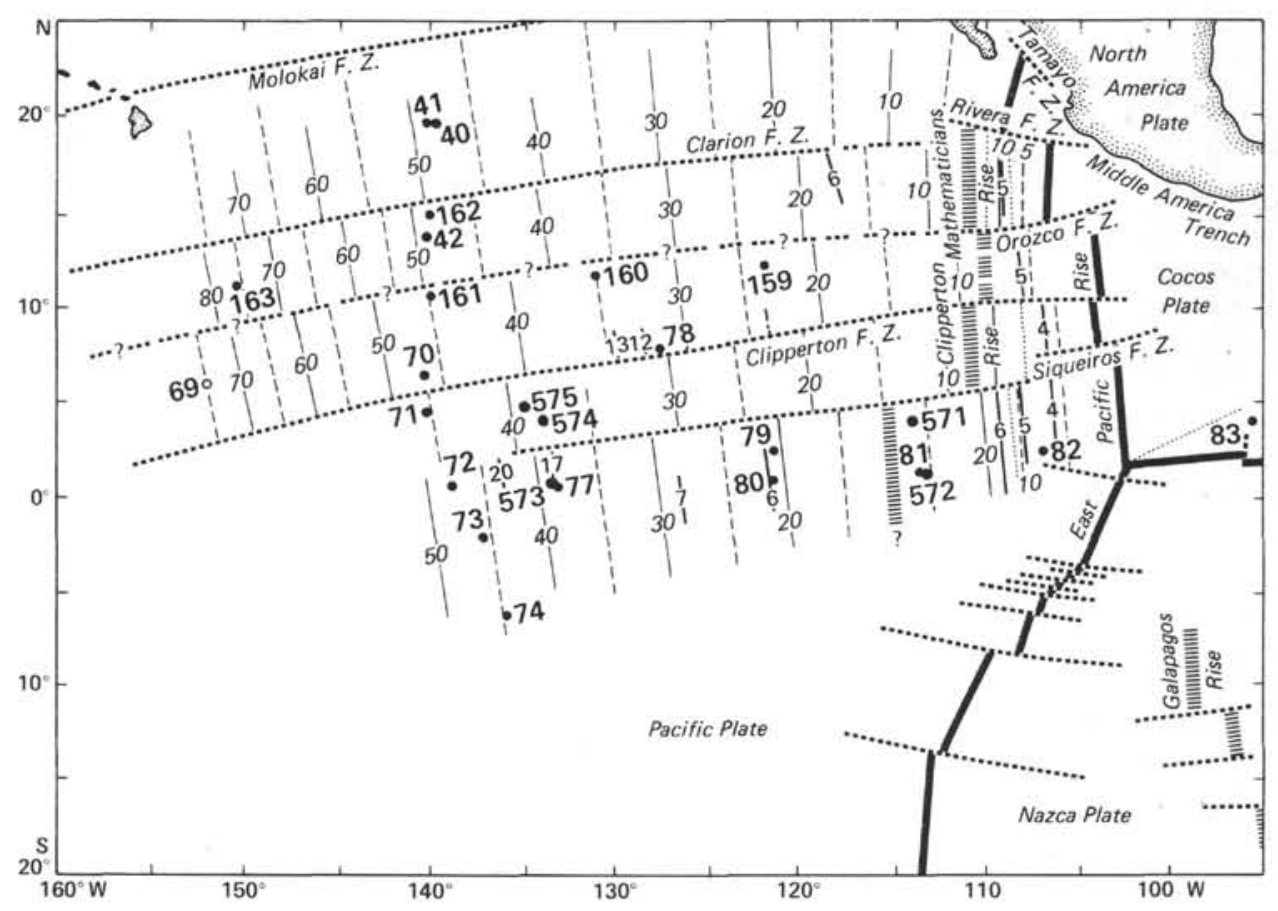

Figure 2. Tectonic setting of the eastern central equatorial Pacific. Numbered dots indicate DSDP drill sites; medium-sized numbers show extrapolated crustal ages (Ma); and small numbers refer to magnetic anomalies. Modified after van Andel et al. (1975).

dominated by carbonate and silica produced by planktonic foraminifers, calcareous nannofossils, diatoms, and radiolarians. Throughout most of the Cenozoic, the relationships between surface-water productivity and sediment accumulation have remained roughly constant, as indicated by the deposition of a more or less lens-shaped body of sediments (Ewing et al., 1968). On a smaller scale, however, this highly productive belt, and its sedimentary expression on the seafloor, is regionally and temporally variable in width (van Andel et al., 1975); today it is roughly 3 to $4^{\circ}$ wide and has its maximum expression slightly offset to the north of the equator. This sedimentary bulge (Fig. 1) is dominated by calcareous sediments along its crest, and it is increasingly more siliceous toward its northern and southern flanks (Winterer, 1973).

The product of this simple tectonic-productivity model of the equatorial region is altered by changes in oceanographic conditions during geological history (van Andel et al., 1975). These temporal changes manifest themselves primarily through fluctuations in the position of dissolution surfaces. In addition, thermohaline currents may physically remove and mix sections of the depositional record. Indeed, numerous submarine outcrops of Tertiary sediments and widespread hiatuses in the equatorial Pacific testify to the effectiveness of bottom-water erosion throughout the Cenozoic (Riedel and Funnell, 1964; Moore, 1970; Johnson, 1972).

\section{DRILLING RESULTS}

Table 1 summarizes locations, operations, and other coring data, and Figures 1 and 2 show the locations of the sites in relation to previous DSDP operations, sediment cover, and basement ages in the region. Figures 3 and 4 summarize the coring operations and the general lithostratigraphy at the sites. The time scale used in this synthesis follows Berggren et al. (in press), in which magnetostratigraphic Chron 11 is correlated with Anomaly 5 (see Barron et al., this volume).

\section{Site $\mathbf{5 7 2}$}

Located at the eastern edge of the equatorial highproductivity zone (Fig. 1; Table 1), Site 572 is several kilometers west of Site 81 (DSDP Leg 9), where only the uppermost and lowermost few meters of the section were recovered. We completed four HPC holes (Fig. 3) and then rotary drilled to a depth of $485.5 \mathrm{~m}$. Basement is at $479.5 \mathrm{~m}$ sub-bottom, and the last core of the site recovered $43 \mathrm{~cm}$ of basalt.

The sedimentary section consists of (Fig. 4) laminated and burrow-mottled siliceous-calcareous oozes and siliceous nannofossil oozes grading to siliceous nannofossil chalks. Cyclic variations in sediment color occur throughout the section and are used to divide the section into four subunits. These subdivisions are arbitrary; sediment color does not appear to be directly related to texture or microfossil composition. The subunits, however, can be recognized in all five holes, and they can be correlated with the "oceanic formations" defined (Hays et al., 1972) for Site 81 . Throughout, and especially in the chalky section, burrows of Chondrites, Planolites, and Zoophy$\cos$ occur. The lowermost samples of the recovered sequence show indications of hydrothermal activity. The entire section is characterized by cyclic alternations between intervals of high ( 80 to $90 \%$ ) and low ( 45 to $65 \%$ ) carbonate content.

Biostratigraphic data indicate that we recovered a continuous sequence (Fig. 4) from upper Pleistocene through 
Table 1. Leg 85 coring summary.

\begin{tabular}{|c|c|c|c|c|c|c|c|c|c|}
\hline Site & $\begin{array}{l}\text { No. } \\
\text { holes }\end{array}$ & $\begin{array}{l}\text { Water depth } \\
\text { (corrected m) }\end{array}$ & Operations & $\begin{array}{l}\text { No. of } \\
\text { received } \\
\text { cores }\end{array}$ & $\begin{array}{l}\text { Maximum } \\
\text { penetration } \\
(\mathrm{m})\end{array}$ & Hole $^{\mathrm{a}}$ & $\begin{array}{c}\text { Cored } \\
\text { sub-bottom } \\
\text { range }(\mathrm{m})\end{array}$ & $\begin{array}{l}\text { Est. age of } \\
\text { oldest seds. } \\
\text { (Ma) }\end{array}$ & $\begin{array}{l}\text { Nature of } \\
\text { basement }\end{array}$ \\
\hline $\begin{array}{c}571 \\
\left(02^{\circ} 59.84^{\prime} \mathrm{N}\right. \\
\left.114^{\circ} 08.53^{\prime} \mathrm{W}\right)\end{array}$ & 1 & 3962 & $\begin{array}{l}\text { HPC; } \\
\text { heat flow/ } \\
\text { pore meter }\end{array}$ & 1 & 7.1 & +571 & $0-7.1$ & - & - \\
\hline $\begin{array}{c}572^{\mathrm{b}} \\
\left(01^{\circ} 26.09^{\prime} \mathrm{N},\right. \\
\left.113^{\circ} 50.52^{\prime} \mathrm{W}\right)\end{array}$ & 5 & 3893 & $\begin{array}{l}\text { Double HPC; } \\
\text { rotary core }\end{array}$ & 76 & 486.0 & $\begin{array}{l}+572 \\
+572 \mathrm{~A} \\
+572 \mathrm{~B} \\
+572 \mathrm{C} \\
572 \mathrm{D}\end{array}$ & $\begin{array}{r}0-19.0 \\
0-154.0 \\
154.0-172.1 \\
0-169.5 \\
151.0-486.0\end{array}$ & $14-15$ & Basalt \\
\hline $\begin{array}{c}573^{\mathrm{C}} \\
\left(00^{\circ} 29.91^{\prime} \mathrm{N},\right. \\
\left.133^{\circ} 18.57^{\prime} \mathrm{W}\right)\end{array}$ & 3 & 4301 & $\begin{array}{c}\text { Double HPC; } \\
\text { rotary core; } \\
\text { heat flow/ } \\
\text { pore water }\end{array}$ & 68 & 529.0 & $\begin{array}{r}+573 \\
+573 \mathrm{~A} \\
573 \mathrm{~B}\end{array}$ & $\begin{array}{c}0-158.6 \\
0-53.2 \\
138.5-529.0\end{array}$ & $38-39$ & Basalt \\
\hline $\begin{array}{c}574 \\
\left(04^{\circ} 12.52^{\prime} \mathrm{N},\right. \\
\left.133^{\circ} 19.81^{\prime} \mathrm{W}\right)\end{array}$ & 4 & 4561 & $\begin{array}{l}\text { Double HPC; } \\
\text { rotary core }\end{array}$ & 92 & 532.5 & $\begin{array}{r}+574 \\
+574 \mathrm{~A} \\
574 \mathrm{~B} \\
574 \mathrm{C}\end{array}$ & $\begin{array}{r}0-206.5 \\
0-180.2 \\
185.0-204.0 \\
194.5-532.5\end{array}$ & $38-39$ & Basalt \\
\hline $\begin{array}{c}575 \\
\left(05^{\circ} 51.00^{\prime} \mathrm{N},\right. \\
\left.135^{\circ} 02.16^{\prime} \mathrm{W}\right)\end{array}$ & 4 & 4536 & Double HPC & 60 & 196.3 & $\begin{array}{l}+575 \\
+575 \mathrm{~A} \\
+575 \mathrm{~B} \\
+575 \mathrm{C}\end{array}$ & $\begin{array}{c}0-98.6 \\
93.8-196.8 \\
0-99.89 \\
0-15.8\end{array}$ & 22 & - \\
\hline
\end{tabular}

\footnotetext{
${ }^{a}$ HPC holes are marked +

${ }^{b}$ Near Site 81 (Leg 9).

$c_{\text {Near Site }} 77$ (Leg 9).
}

the lowest middle Miocene (about $15 \mathrm{Ma}$ ). Holocene and uppermost Pleistocene sediments were apparently lost in the coring process. All major microfossil groups are represented at Site 572. Siliceous microfossils occur in common to high abundances throughout the section, and calcareous microfossils are abundant and well preserved throughout the Pliocene and Pleistocene. A sharp break in carbonate preservation occurs at approximately 150 $\mathrm{m}$ sub-bottom (uppermost Miocene, about $6 \mathrm{Ma}$ ). From this level down to the lowermost part of the section (435 $\mathrm{m}$, middle Miocene), calcareous microfossils are represented by species with particularly high dissolution indices (Berger and von Rad, 1972). Well preserved assemblages reappear in the three deepest core (436 to 464.5 $\mathrm{m}$, middle Miocene, 14 to $15 \mathrm{Ma}$ ). Radiolarians are well preserved throughout the section, whereas diatoms show good preservation above $365 \mathrm{~m}$ sub-bottom and generally poor to moderate preservation below that level. High percentages of the diatoms Thallassionema nitzschioides and Thalassiothrix longissima, which are thought to indicate upwelling, dominate the intervals from 64 to $218 \mathrm{~m}$ and from 246 to $322 \mathrm{~m}$.

Sediment accumulation rates at Site 572 have been variable, and, in some intervals, remarkably high (Fig. 5). The rate from about 12 to $15 \mathrm{Ma}$ averaged approximately $32 \mathrm{~m} / \mathrm{m}$.y., whereas early Pliocene to latest Miocene (3.8 to $6.4 \mathrm{Ma}$ ) rates varied between 46 and $67 \mathrm{~m} / \mathrm{m}$.y. Between the 5- and 8-Ma levels, $\mathrm{CaCO}_{3}$ percentages are relatively low $(\sim 70 \%)$, implying dilution of carbonate by biogenic silica during periods of high sedimentation rate. Comparison of carbonate and noncarbonate accumulation rates (Fig. 6) reveals that when accumulation rates shift from low to high, the carbonate accumulation rate increases by a factor of 3 while the noncarbonate (mainly biogenic silica) rate increases by a factor of 6 .

\section{Site 573}

The southernmost of the north-south line of sites across the equatorial sediment bulge, Site 573 (Fig. 1, Table 1), was selected as a high-resolution duplicate of DSDP Site 77 (Hays et al., 1972). Whereas Site 77 was drilled on the flank of a basement ridge with $0.51 \mathrm{~s}$ of sediment cover, Site 573 is located over a basement trough covered by $0.62 \mathrm{~s}$ of acoustically well stratified sediment.

The oldest sediment recovered (Fig. 5) is uppermost Eocene limestone (Hole 573B, $528 \mathrm{~m}$ ), separated by a baked sediment interface from basalt with glassy rinds (1 m recovered). Four lithostratigraphic units can be recognized, which correlated with the three oceanic formations established at Site 77 (Hays et al., 1972).

Planktonic foraminifers, calcareous nannofossils, radiolarians, and diatoms are, with exceptions, well represented in the sediments, allowing recognition of nearly all standard Eocene to Quaternary biozonal boundaries; but the Eocene/Oligocene boundary could not be located unequivocally. Biostratigraphic evidence points to the presence of seven hiatuses and two intervals of very slow sediment accumulation rates in the cored sequence (Barron et al., this volume; also Fig. 5). A prominent hiatus is bracketed by foraminiferal Zones P16 (uppermost Eocene) and P18 (basal Oligocene) and nannofossil Subzones CP15b (Eocene) and CP16b (Oligocene). This absence of foraminiferal Zone P17 may also be explained, however, by assuming that the metalliferous claystone between 520.5 and $528 \mathrm{~m}$ (Fig. 4) represents a greatly compressed depositional record of latest Eocene to earliest Oligocene time. Perhaps the metalliferous layer is the remnant of a normal biogenic ooze from which hydrothermal activity has removed all microfossils by solution. Three hiatuses follow in the topmost Oligocene and 


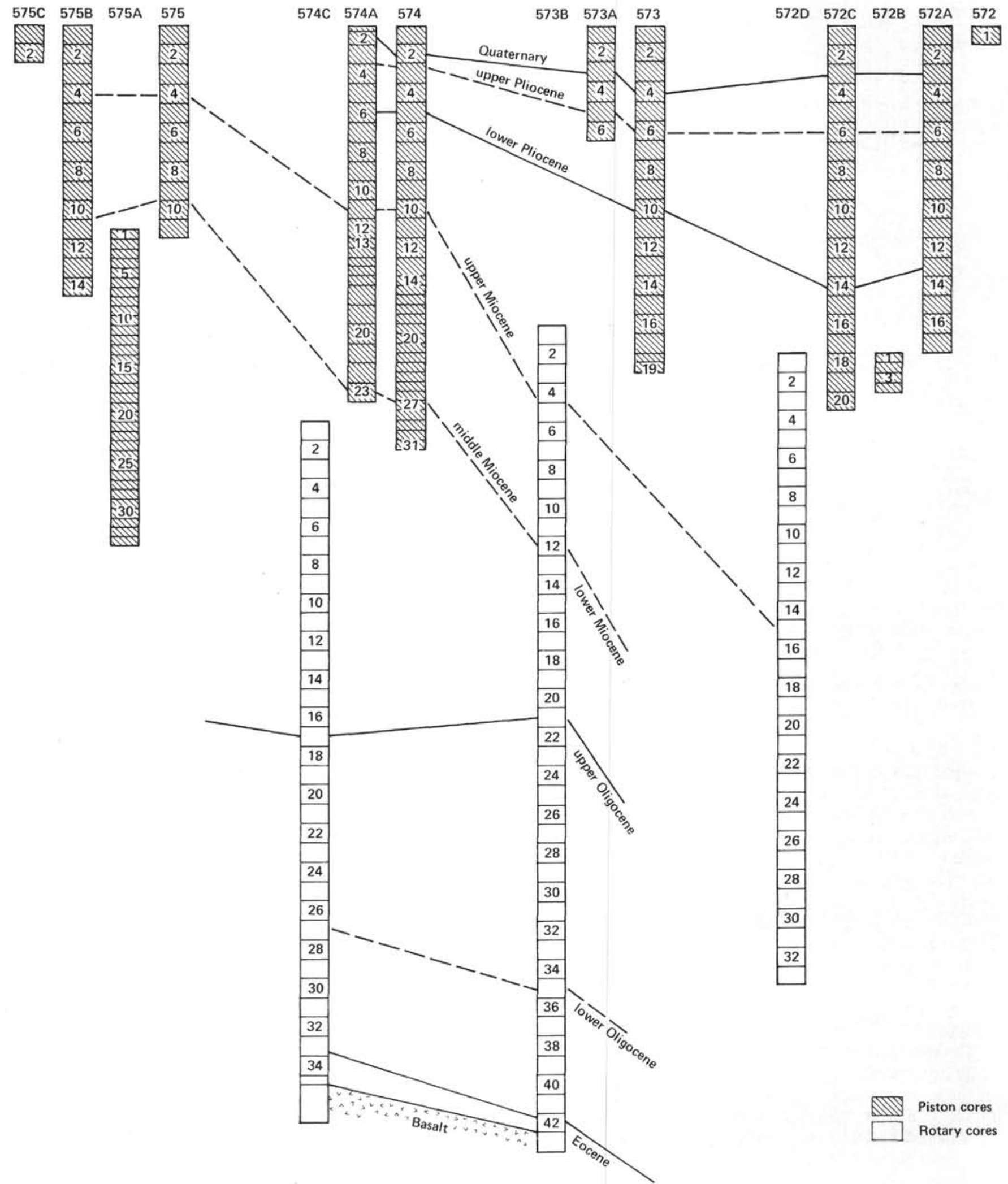

Figure 3. Holes cored and drilled during Leg 85 . Hatching indicates VLHPC cores; others were rotary drilled. The cores generally measure 5 or $9 \mathrm{~m}$ in length. 


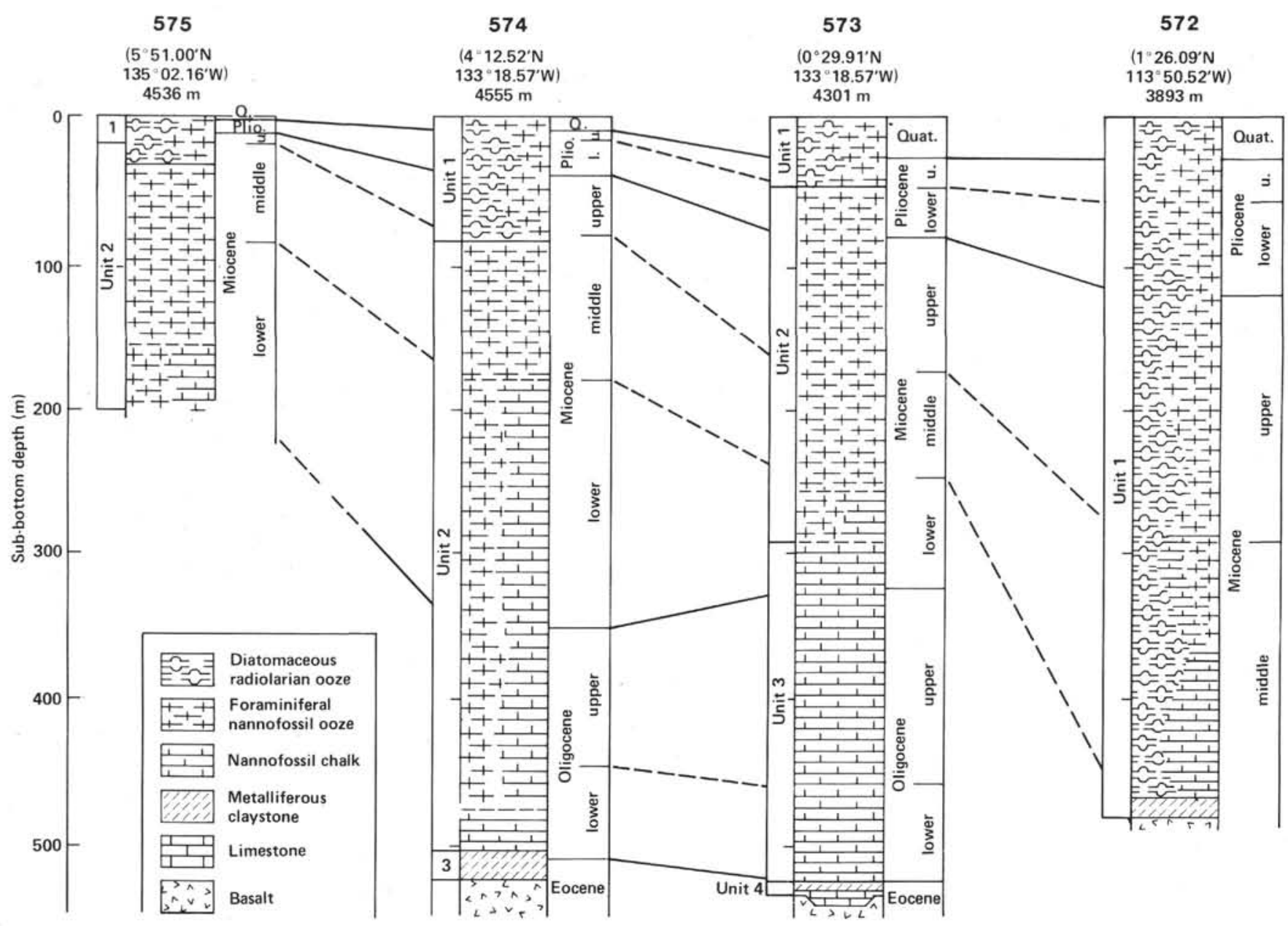

Figure 4. Generalized lithology and stratigraphy of Sites 572 through 575. Stratigraphic boundaries follow time scale based on foraminiferal, nannofossil, radiolarian, and diatom datum levels (see Barron et al., this volume).

lower Miocene, and three more occur in the middle and upper Miocene (Fig. 5). At nearby Site 77, correlative gaps were found in the record (Hays et al., 1972).

Sediment accumulation rates at Site 573 varied generally between 10 and $35 \mathrm{~m} / \mathrm{m}$.y. (Fig. 5). Two peaks exceeding $30 \mathrm{~m} / \mathrm{m}$.y. occurred between 5 and $6 \mathrm{Ma}$ (latest Miocene) and from about 32 to $35 \mathrm{Ma}$ (earliest Oligocene). In some instances, the changes in accumulation rate correlate with lithologic contrasts. Thus, the silicarich sediments between about 160 and $200 \mathrm{~m}$ contain three hiatuses, and the brown sedimentary unit between 260 and $360 \mathrm{~m}$ is roughly equivalent to a time of slow accumulation and hiatus formation (Barron et al., this volume).

Compaction has a marked effect on estimates of sediment accumulation rate, as demonstrated by calculations of mass accumulation rate (Fig. 6). For example, the intervals from 4 to $8 \mathrm{Ma}$ and from 30 to $33 \mathrm{Ma}$ show similar rates of sediment accumulation, yet mass accumulation rates in the Oligocene chalks are significantly higher than in the Pliocene/Pleistocene sediments.

\section{Site 574}

Site 574 (Fig. 1; Table 1) is the second of a three-site north-south transect across the equatorial high-produc- tivity zone. Its position (near the crest of the equatorial sediment bulge) was selected to provide a sediment record of the migration of this site across the equator and to permit recovery of the Eocene/Oligocene boundary. The section at Site 574 is divided, primarily on the basis of sediment composition (Fig. 4), into three lithologic units: (1) a cyclic siliceous-calcareous ooze unit, (2) a calcareous ooze/chalk unit, and (3) a metalliferous calcareous unit.

Stratigraphically important is the remarkably complete recovery, at this site, of the transition from the uppermost Eocene to the lowermost Oligocene. This transition occurs in the metalliferous unit $(502.5$ to $520.0 \mathrm{~m})$ directly above basement (Fig. 4), the boundary's precise location varying with the microfossil zonations.

The major microfossil groups are generally well represented, providing a fairly complete uppermost Eocene to Quaternary section. Siliceous microfossils are abundant and well preserved in most of the section. Diatom abundance and preservation, however, decline in the upper Oligocene, the upper part of the lower Oligocene, and near the Eocene/Oligocene boundary. Planktonic foraminiferal abundances fluctuate, and this group provides good stratigraphic control only in the lower middle Miocene. Calcareous nannofossils are common to 


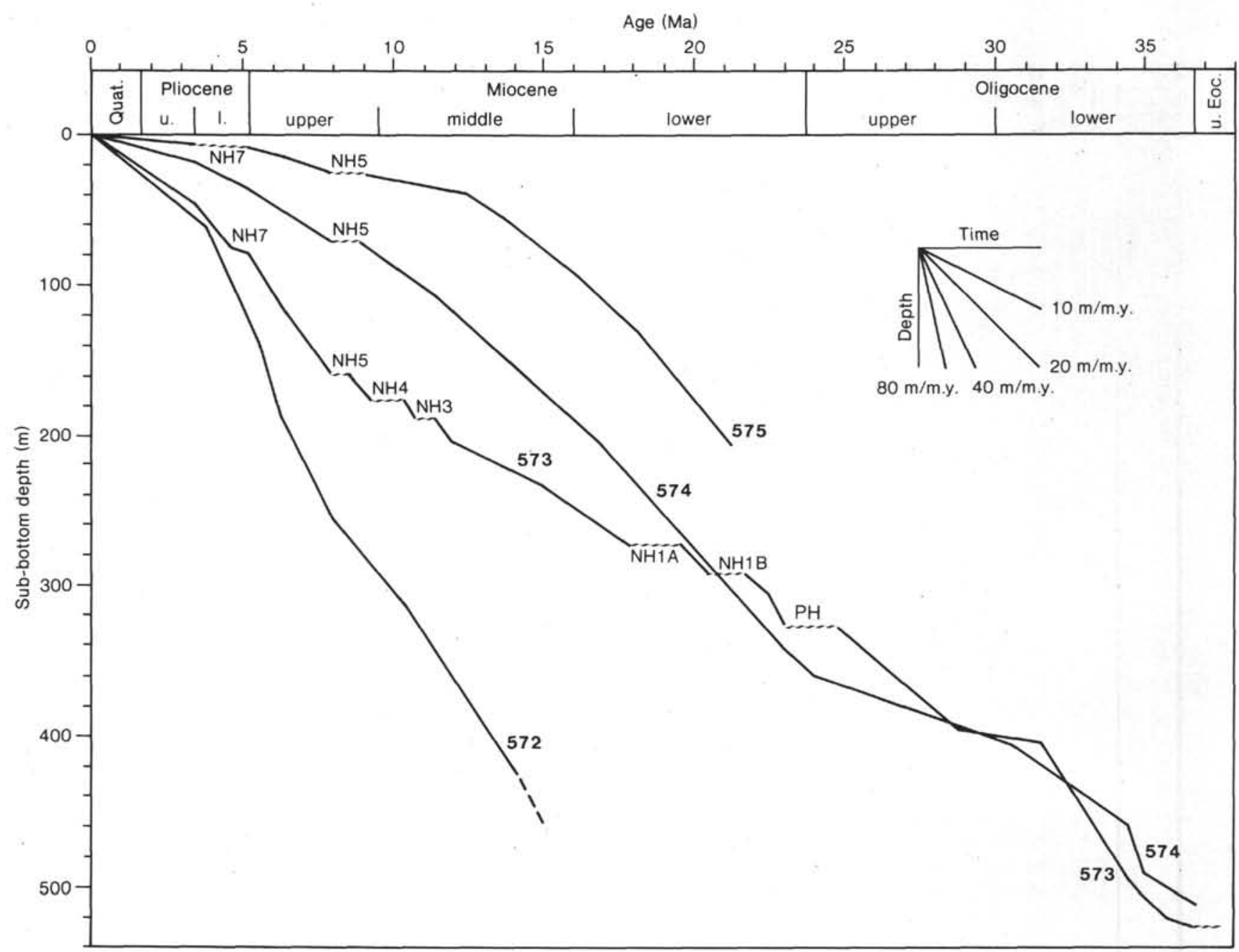

Figure 5. Sediment accumulation rates at Sites 572 through 575. Breaks denote hiatuses or extremely slow accumulation. The time scale follows Barron et al. (this volume), and NH numbers and PH are hiatuses after Barron and Keller (1982).

abundant throughout the section. Reworked Oligocene foraminifers and nannofossils occur in three zones of the middle Miocene.

Sediment accumulation rates at Site 574 are moderate. Oligocene rates average about $12 \mathrm{~m} / \mathrm{m}$.y., increasing to $20 \mathrm{~m} / \mathrm{m}$.y. in the lower to middle Miocene (Fig. 5). Above this level they decrease and remain low, and a hiatus occurs at $70 \mathrm{~m}$ sub-bottom ( 7.8 to $8.8 \mathrm{Ma}$ ). In contrast to Sites 572 and the upper section at Site 473 , the sediment accumulation rate at Site $\mathbf{5 7 4}$ is strongly dominated by calcium carbonate: high mass accumulation rates occur during times of little biogenic silica deposition (Fig. 6).

\section{Site 575}

Site 575, just south of the Clipperton Fracture Zone (Table 1; Fig. 1), completes a three-site latitudinal transect along approximately $133^{\circ} \mathrm{W}$, across the equatorial sedimentary "bulge." Time limitations prevented completion of drilling to basement, but the paleoenvironment and stratigraphic objectives were satisfied by four HPC holes (Fig. 3) that penetrated to $196.3 \mathrm{~m}$ sub-bottom and ended in lowermost Miocene (Fig. 4). A com- bined total of $374.47 \mathrm{~m}$ (the upper $120 \mathrm{~m}$ overlap) of sediments was recovered, mostly undisturbed.

The lower to middle Miocene part of the section records a highly productive environment dominated by equatorial sedimentation, whereas the upper part of the section testifies to the site's northward migration from under the equatorial belt system. Two lithologic units were identified, an upper Miocene to Quaternary calcareous cyclic unit ( 0 to $32.2 \mathrm{~m}$ sub-bottom) and a siliceous-calcareous ooze/chalk unit (32.3 to $196.2 \mathrm{~m})$. The upper unit is characterized by cyclic alternations in carbonate content, whereas the lower unit has relatively constant, high $(94 \%)$ carbonate values down to the lower Miocene, where mean carbonate percentages decrease slightly $(86 \%)$. Subunits, based primarily on color, can be distinguished in both units. Centimeter-thick sandy to pebbly turbidites, composed primarily of allochthonous foraminifers and volcanic debris, are interbedded throughout the section. A large seamount $10 \mathrm{~km}$ northeast of the site, and rising $1000 \mathrm{~m}$ above the regional seafloor, is the most likely source of these turbidites.

All major microfossil groups occur throughout, although preservation of calcareous skeletons is poor to 


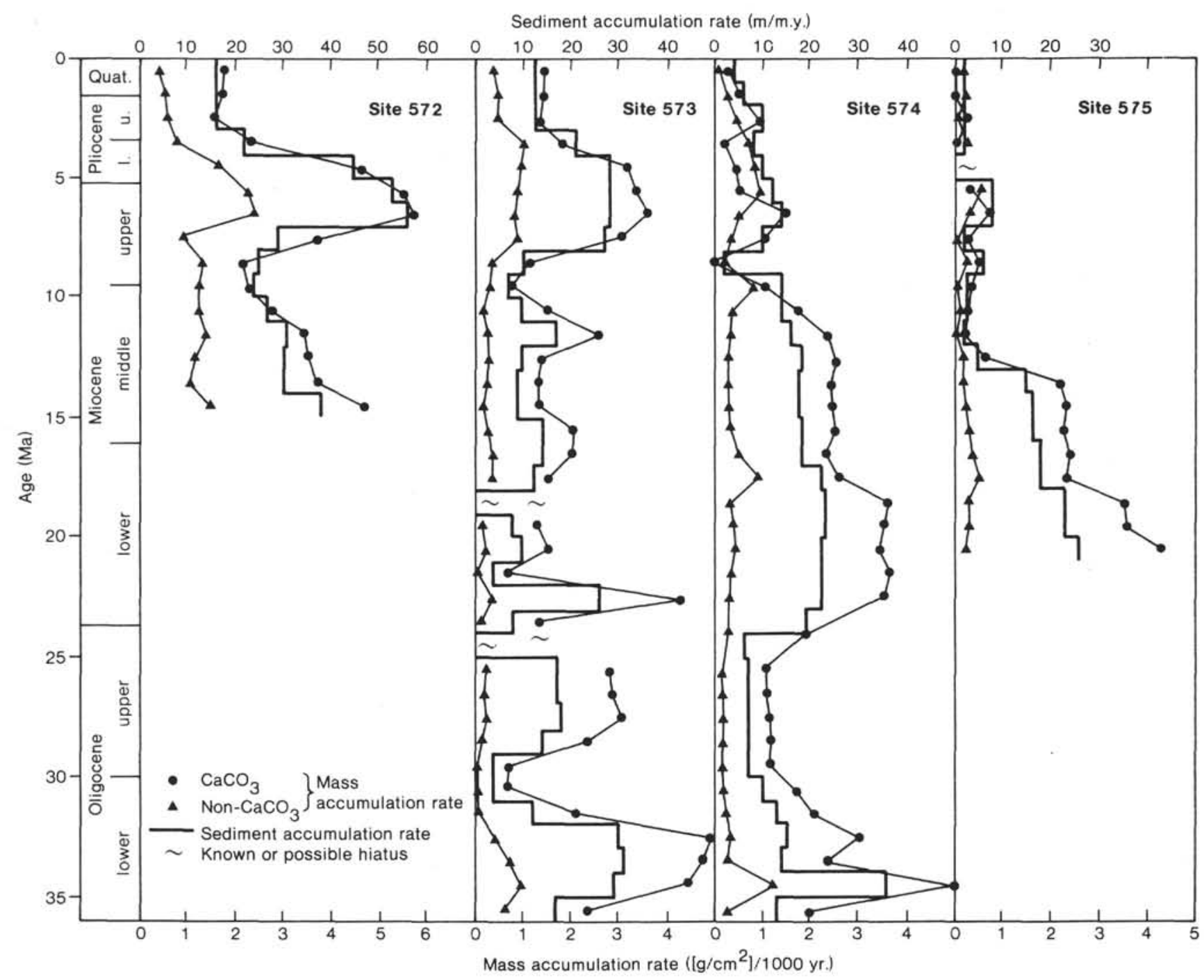

Figure 6. Sediment accumulation rates and carbonate and noncarbonate mass accumulation rates versus age for Sites 572 through 575 .

almost nil in the topmost siliceous-calcareous cyclic unit. Calcareous dissolution is pervasive in the uppermost unit and is compounded by microfossil reworking and the extreme stratigraphic compression of the section, obscuring recognition of some biozonal boundaries. In contrast, the expanded character of the ooze/chalk unit and the excellent preservation of microfossils (except for a brief interval from 102 to $108 \mathrm{~m}$ sub-bottom, about $16.5 \mathrm{Ma}$ ) make it one of the most complete lower Neogene sequences available from the equatorial Pacific.

Sediment accumulation-rate fluctuations (Fig. 5) correlate with the lithostratigraphic subdivisions. Moderate rates of about $20 \mathrm{~m} / \mathrm{m}$.y. characterize the oozes of the lower unit; low rates typify the siliceous-calcareous unit, which is also marked by two hiatuses, one at $8 \mathrm{~m}$ (3.4 to $5.1 \mathrm{Ma})$ and one at $26 \mathrm{~m}(7.8$ to $9.2 \mathrm{Ma})$ sub-bottom depth.

\section{ELEMENTS FOR A SYNTHESIS}

\section{Overall Trends}

The geographic distribution of the Leg 85 sites permits a longitudinal, latitudinal, and temporal evaluation of the major influences on equatorial pelagic deposition. Except for the relatively thin metalliferous layers of hydrothermal origin (Jarvis, this volume) at the base of each section (Fig. 4), the major compositional changes in the recovered sediments result from shifts in the relative abundances of the preserved biogenic siliceous or calcareous components.

The fundamental causes of these sedimentation shifts are obvious: all Leg 85 sites subsided and migrated from relatively shallow (about $3000-\mathrm{m}$ ) depths in the eastern Pacific, south of the equator, to deeper (4000- to 4600-m), more western locations at or north of the equator (Fig. 3). This northwesterly migration proceeded at about $0.3 \mathrm{~cm} /$ yr. (Weinreich and Theyer, this volume). During their migration and subsidence, the sites passed first under the equatorial high-productivity zone, where biogenic silica and carbonate sedimentation rates increased and the CCD (carbonate compensation depth) is depressed. While under this zone, fluctuations of the width of the equatorial high-productivity zone, and of latitudinal and longitudinal gradients in productivity (biogenic sedimentation), were imprinted on the sedimentary records. Then, continued subsidence and northwesterly migration of the sites 
beyond the equatorial high-productivity zone led to increased carbonate dissolution in their sequences. Thus, this basic, tectonically driven system is complicated by imprints left in the record from temporal variations in productivity, dissolution, and erosion. These temporal changes may range from global paleoclimatic shifts to regional events.

The most striking overall characteristic of the region is a strong east-west depositional gradient, prevailing from middle Miocene to Recent (Fig. 7). At Site $572\left(114^{\circ} \mathrm{W}\right)$, overall sedimentation and accumulation rates are highest (often more than $40 \mathrm{~m} / \mathrm{m}$.y.; Fig. 5), whereas, in comparison, at Site 573 (about $2100 \mathrm{~km}$ to the west), rates are clearly attenuated in sections older than 5 to $8 \mathrm{Ma}$ (Fig. 5). Water depth and latitude influence the differences between Sites 572 and 573. More important, however, the carbonate and noncarbonate accumulation rates (Fig. 8), the foraminiferal dissolution index, and qualitative evaluation of diatom and benthic foraminiferal species distribution all support the idea that the strong east-west gradient is the sedimentary expression of a surface-water primary productivity trend similar to that observed today (Austin, 1960; Koblentz-Mishke et al., 1970). Indeed, the lithologic and stratigraphic variation from east to west may be primarily due to a strong east-towest decrease in diatom productivity. Assuming that the noncarbonate component in this region is mainly bio- genic silica, this increasing influence of silica productivity in the east is also shown by a comparison of the carbonate and noncarbonate accumulation rates (Fig. 6). Moreover, diatom species indicative of upwelling are abundant at times of increased noncarbonate accumulation. For Site 572, a plot of carbonate rate vs. noncarbonate rate shows a positive, linear relationship (Fig. 8). For Site 573 , the data reveal a similar trend, but the noncarbonate component is less dominant.

The influence of the east-west productivity gradient is particularly noticeable when one compares sedimentation rates, mass accumulation rates (Figs. 5, 6, 8), carbonate content, and dissolution-index curves (Mayer et al., this volume; Saito, this volume) of Sites 572 and 573. At Site 573, the carbonate and noncarbonate accumulation rates and carbonate contents track nicely: high carbonate values are associated with high accumulation rates (productivity) and better preservation. At Site 572, however, the same relationship occurs only during periods of relatively lower accumulation rates; times of highest accumulation are associated with enhanced dissolution of $\mathrm{CaCO}_{3}$ and decreased carbonate content. A possible explanation for these differences between the sites may depend on the magnitude of noncarbonate accumulation at each site. The highest noncarbonate rate at Site 573 is about $0.5 \mathrm{~g} / \mathrm{cm}^{2} / 1000 \mathrm{yr}$., whereas the maximum value at Site 572 is almost three times that amount.

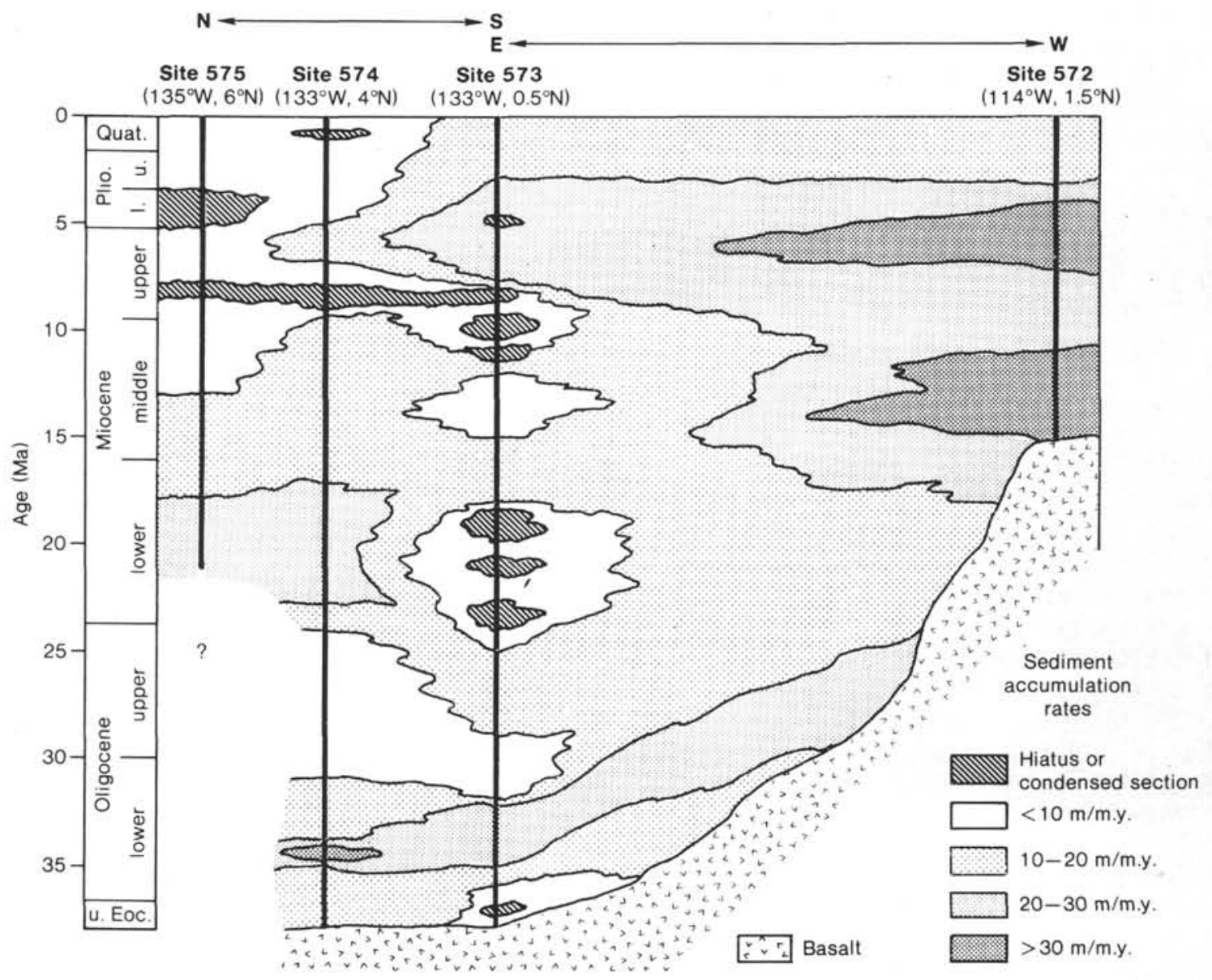

Figure 7. Schematic model of overall sedimentation trends (east-west, north-south) at Sites 572 to 575. 

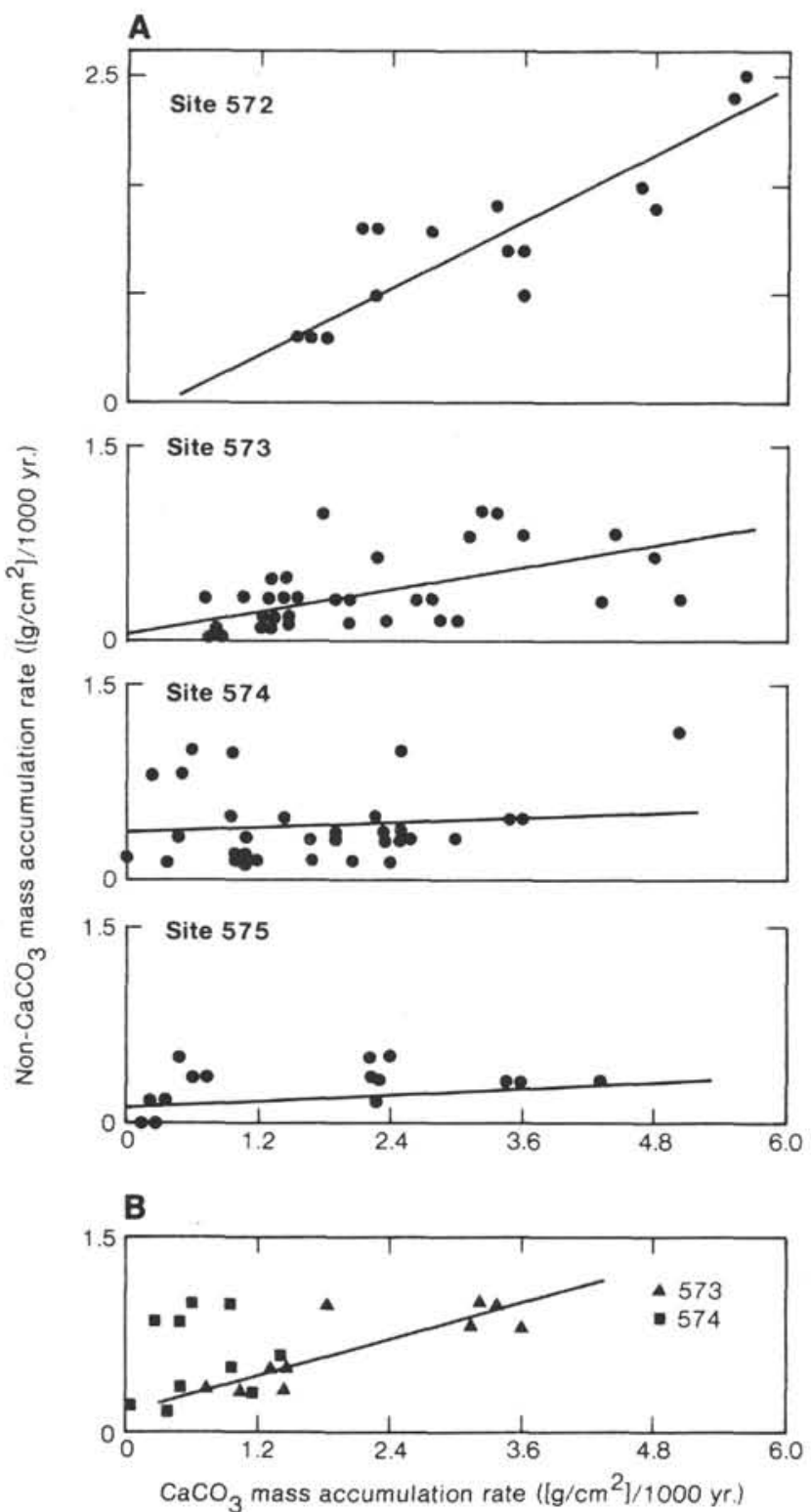

Figure 8. Correlation between carbonate and noncarbonate (presumed to be mostly biogenic silica) mass accumulation rates for Sites 572 through 575. A. Single-site comparison. B. Data for the last 10 m.y. from Sites 573 and 574, plotted together; regression line based on Site 573.

We suggest that when a certain noncarbonate accumulation-rate (productivity) threshold is reached, oxidation of the abundant organic matter produces steep dissolution gradients and enhanced dissolution.

A latitudinal trend in deposition is apparent between Site 573, 574, and 575 from about middle Miocene to Recent (Figs. 4 to 8 ), but it is less pronounced than the east-west gradient. This latitudinal trend of the last 15 m.y. appears to be predominantly the result of enhanced dissolution to the north. At Sites 574 and 575, we find a correlation of low sediment accumulation rates and low percent calcium carbonate. At Sites 572 and 573 (the equatorial belt sites), we find high sediment accumulation rates correlated with low percent $\mathrm{CaCO}_{3}$, implying that $\mathrm{CaCO}_{3}$ was removed from the northern sites while
$\mathrm{SiO}_{2}$ was added to equatorial sites. In the lower Miocene, however, the sense of the latitudinal trend is reversed: sediment accumulation rates at Sites 574 and 575 exceed those of Site 573 (Fig. 7). This temporal change in the latitudinal sense of the depositional trend, which occurs at about $15 \mathrm{Ma}$, may be the result of the passage of the sites beneath the equatorial high-productivity zone. Sites 574 and 575 were close to or at the equator between 15 and $20 \mathrm{Ma}$ (Weinreich and Theyer, this volume), and Site 573 was at about $5^{\circ} \mathrm{S}$. Then, at the beginning of the middle Miocene, Sites 574 and 575 moved away from the equator, causing a sequential decrease in sediment accumulation rates at both sites-first at Site 575 (at about $13 \mathrm{Ma}$ ) and then at Site 574 (at about 9 Ma). Thus, these data suggest that the effect of the highproductivity zone along the equator has not changed since the early Miocene: deposition at a particular site is clearly affected when that site is at the equator.

Oligocene was recovered only at Sites 573 and 574. At Sites 573 and 574, we recovered the most complete Oligocene carbonate records of the equatorial Pacific. Although few data are presently available, we can say that sediment accumulation rates at both sites were relatively low in the late Oligocene and high in the early Oligocene, and that greater overall variability characterized Site 573.

Finally, an impressive example of a temporal trend is the major shift in the nature of carbonate deposition which occurs near the time of the middle/upper Miocene boundary at Sites 573,574 , and 575 . Not only is there a hiatus or very compressed interval at about 8 to $9 \mathrm{Ma}$ at all sites, but sediments deposited after the middle Miocene generally have a highly variable carbonate content, whereas sediments predating late Miocene have a relatively constant high carbonate content (Fig. 4; see site chapters). Associated with this shift from carbonate-silica cycles to high-carbonate sediments are significant changes in the physical, chemical, and magnetic properties (see site chapters; Mayer et al.; Wilkens and Handyside; Weinreich and Theyer; all this volume).This shift from a carbonate to a carbonate-silica regime near the time of the middle/upper Miocene boundary may be linked to worldwide cooling and to the change of the major sink for silica from Atlantic to Pacific (Keller and Barron, 1983).

\section{Central Pacific Paleoceanography}

Paleoceanographic results of Leg 85 contributed to advances in four key areas: (1) A high-resolution, multidisciplinary, and integrated datum-plane correlation scheme and time scale for the central equatorial Pacific is now largely completed (Barron et al., in press; Barron et al., this volume; Berggren et al., in press; Keller et al., 1982; Pisias et al., stratigraphic resolution, this volume; Saito et al., 1975; Theyer et al., 1978). (2) A system of correlative acoustic reflectors (Embley and Johnson, 1980; Mayer, 1979a, b; Schlanger and Douglas, 1974; Shipley et al., this volume) is being delineated over vast distances in the biogenic Tertiary sediments of the region (Mayer et al., this volume). (3) Fine-scale, global to regional geochemical and micropaleontological climatic 
reconstructions are beginning to emerge for the Tertiary (Barron, this volume; Bukry, this volume; Hays et al., 1969, 1972; Keller, 1983; Miller and Thomas, this volume; Pisias et al., isotope studies, Site 574, this volume; Prell, this volume; Shackleton and Opdyke, 1973; Thomas, this volume; Vincent and Killingley, this volume; Woodruff et al., 1981). (4) A recurring punctuation of the Tertiary deep-sea record by widely correlative hiatuses or drastic accumulation-rate reductions is finding ever-increasing documentation (Barron and Keller, 1982; Keller and Barron, 1983; Barron et al., this volume).

Although the "absolute" time scale may be the least absolute reference frame available to geologists, it is the first element of any synthesis. And, in terms of correlative power and resolution, we have made vast gains; to appreciate this, one need only compare the biostratigraphic synthesis of DSDP Leg 7 (Hays et al., 1972) with that of the present volume (Barron et al., this volume). Much of this increase in stratigraphic power is directly attributable to the recovery of continuous and barely disturbed HPC sections. Given that our typical sampling interval was $1.5 \mathrm{~m}$, the practical limit of resolution for most of the Tertiary sections cored on Leg 85 is 0.13 to $0.38 \mathrm{~m}$.y. (Barron et al., this volume; Pisias et al., stratigraphic resolution, this volume), and much higher resolution is obviously possible with closer sampling (e.g., Pisias et al., isotope studies, Site 574, this volume). Thus, our chronostratigraphic framework approaches resolutions that allow reliable detection and correlation, over large distances, of at least the major Tertiary oceanographic events that we presently know (Berger, 1982; Keller and Barron, 1983; Kennett, 1983; Loutit and Keigwin, 1982; Vail and Hardenbol, 1979). This level of chronostratigraphic resolution in compositionally different sequences is of fundamental importance; without it, attempts to trace and understand global-or even regional-events lasting 0.01 to $0.1 \mathrm{~m} . \mathrm{y}$. will, even though important, yield only generalized results (Keller and Barron, 1983; Vail et al., 1977). A single short event may appear as a hiatus in one sequence, as a cooling event in another, as a sea-level change in yet another, and may result in a distinct acoustic horizon elsewhere. Given possible local distortions of the sedimentary record, only precise cross-correlation would allow us to sort through such a plethora of depositional expression.

The second element of broad significance for a general synthesis of the central Pacific's paleoceanographic history may also be the most fascinating overall result of the drilling. A system of correlatable Tertiary seismic reflectors, spanning vast areas of the carbonate-bearing sediments of the central Pacific, was defined (Mayer et al., this volume). This seismic record of paleoceanographic events results from sedimentary contrasts left in the depositional record by the physical and chemical changes associated with the global events summarized in Table 2. Once each reflector is further understood and defined at several more drill sites, we could enter a phase of rapid and large-scale paleoceanographic assessment and mapping using remote sensing techniques. This possibility holds significant promise for the rapid advancement of this branch of geology.
The third component of an eventual regional paleoceanographic synthesis is a thorough understanding of the climatic and oceanographic cycles and changes that shaped the Tertiary central Pacific depositional record. This understanding is being rapidly achieved. Discrete and significant Tertiary isotopic and carbonate events (Table 2) are discussed in the contributions to this volume (upper Eocene to Oligocene isotopic record of benthic foraminifers [Miller and Thomas]; isotopic analyses of planktonic and benthic foraminifers in the lowermost Miocene to middle Miocene [Vincent and Killingley; Pisias et al.]; and studies of portions of the upper Miocene to Pleistocene geochemical record [Pisias and Prell; Prell]). These geochemical studies are complemented by an evaluation, using micropaleontological data, of oceanographic events ranging from the late Eocene to the Quaternary (Thomas; Barron; Bukry; Saito; Pujos; Labracherie). Despite the discontinuous nature of these studies, and the current uncertainties associated with parts of the "absolute" time scale (Barron et al., this volume), a sequence of regionally correlatable paleoceanographic events is slowly evolving from these multidisciplinary investigations (Table 2; also Mayer et al., this volume).

The final category of studies that will help in elucidating a unified paleoceanographic view of broader scale lies in the ever-widening recognition that the oceanic depositional record is punctuated by recurrent and correlatable hiatuses or drastic decreases of sedimentation rates (Johnson, 1972; van Andel et al., 1975; Moore et al., 1978; Barron and Keller, 1982; Keller and Barron, 1983). Although some oceanic hiatuses are local phenomena, many are likely to be synchronous depositional expressions of global paleoceanographic variations. The latter possibility is reflected in the temporal and spatial incidence and variations of hiatuses, both within and between major ocean basins (Moore et al., 1978; Keller and Barron, 1983). Even though deposition at the easternmost site of Leg 85 (Site 572) was under such highly productive waters that no hiatuses were detected (Barron et al., this volume), sections at Sites 573 to 575 contain prominent examples of these correlative hiatuses or compressed depositional records (Figs. 4 to 7), beginning with the time of the Eocene/Oligocene boundary. Most of these can be correlated (Fig. 5; also Barron et al., this volume) with the "NH" hiatus system developed by Barron and Keller (1982).

According to Moore et al. (1978), hiatuses result when the rate of sediment removal (by dissolution or bottomcurrent erosion) exceeds the rate of sediment supply (dominantly biological productivity in this region). Barron and Keller (1982) showed that the NH hiatuses occurred during times of polar cooling, except for NH2 (15 to 16 Ma). The authors inferred increased production of Antarctic Bottom Water during such episodes of polar cooling to be the active erosive/corrosive force responsible for the hiatuses. It is also possible for decreased biological productivity to cause hiatuses by reducing the rate of biogenic sediment supply relative to the rate of sediment removal. Although the Leg 85 sites allow an initial assessment of Tertiary productivity changes (discussed ear- 
Table 2. Seismic reflectors of the eastern central equatorial Pacific, their age, sedimentary causes, and associated events.

\begin{tabular}{|c|c|c|c|c|c|c|}
\hline Reflector & $\begin{array}{l}\mathrm{Age}^{\mathrm{a}} \\
(\mathrm{Ma})\end{array}$ & Impedance ${ }^{b}$ & Primary cause ${ }^{b}$ & $\begin{array}{l}\text { Geochemical } \\
\text { events }\end{array}$ & Hiatus $^{c}$ & $\begin{array}{l}\text { Paleoceanographic } \\
\text { events }^{d}\end{array}$ \\
\hline Green & $3-4$ & Large density contrast & Carbonate minimum & $\begin{array}{l}\delta^{18} \mathrm{O} \text { enrichment }{ }^{\mathrm{e}} ; \mathrm{CaCO}_{3} \\
\text { dissolution }\end{array}$ & - & $\begin{array}{l}\text { N. Hemisphere glaciation; N. Atlan- } \\
\text { tic erosion; closing of Panama } \\
\text { Isthmus }\end{array}$ \\
\hline Brown & $6.5-7.5$ & Large density contrast & Carbonate minimum & Chron $6 \delta^{13} \mathrm{C}$ depletion & NH6 & Climatic deterioration \\
\hline Purple & $8.5-9.5$ & Large density contrast & $\begin{array}{l}\text { Extreme carbonate } \\
\text { minimum }\end{array}$ & $\begin{array}{l}{ }^{5}{ }^{18} \mathrm{O} \text { enrichment } \mathrm{f} ; \text { mid- } \\
\text { Chron } 10 \mathrm{CaCO}_{3} \\
\text { dissolutiong }\end{array}$ & $\begin{array}{l}\text { NH5? } \\
\text { NH4? }\end{array}$ & $\begin{array}{l}\text { Major N. Atlantic erosion; increase of } \\
\text { siliceous deposition in Pacific; } \\
\text { major cooling; major drop in sea } \\
\text { levels }\end{array}$ \\
\hline Red & $13.5-14.5$ & $\begin{array}{l}\text { Large density, small } \\
\text { velocity contrast }\end{array}$ & Carbonate minimum & $\begin{array}{l}\text { 15. } \mathrm{CaCO}_{3} \text { dissolution } \\
\text { event } \mathrm{h}^{\mathrm{h}} ; 1 \%_{0} \delta_{0} \delta^{18} \mathrm{O} \\
\text { enrichment } \mathrm{t}^{\mathrm{i}, \mathrm{j}}\end{array}$ & NH3 & $\begin{array}{l}\text { Ice buildup in Antarctica; intensifica- } \\
\text { tion of Antarctic Bottom Water }\end{array}$ \\
\hline Lavender & $16-17$ & $\begin{array}{l}\text { Very large density, } \\
\text { very small veloc- } \\
\text { ity contrast }\end{array}$ & Carbonate minimum & $\begin{array}{l}\text { 16 } \mathrm{g} \mathrm{CaCO}_{3} \text { dissolution } \\
\text { event }^{\mathrm{k}} ; \text { Chron } 16 \delta^{13} \mathrm{C} \\
\text { shift }^{\mathrm{i}}\end{array}$ & $\mathrm{NH} 2$ & $\begin{array}{l}\text { Closing of Tethys; Norwegian sea spill; } \\
\text { intensified Pacific upwelling }\end{array}$ \\
\hline $\begin{array}{l}\text { Yellow- } \\
\text { Orange }\end{array}$ & $20.5-22.5$ & $\begin{array}{l}\text { Large velocity, small } \\
\text { density contrast }\end{array}$ & Diagenesis & $\begin{array}{l}\text { Interval of high } \delta^{13} \mathrm{C} \\
\quad(\text { Events } \mathrm{A}, \mathrm{B})^{\mathrm{i}}\end{array}$ & PH? & $\begin{array}{l}\text { Opening of Drake Passage; establish- } \\
\text { ment of Circum-Antarctic Current } \\
\text { and of steep N-S thermal gradients }\end{array}$ \\
\hline
\end{tabular}

a Barron et al. (this volume).

b Based on Site 574 (Mayer et al., this volume).

c Barron and Keller (1982); Keller and Barron (1983).

d Discussed in Mayer et al., (this volume).

e Prell (this volume).

f Savin et al. (1981).

$g$ Vincent (1981).

$\mathrm{h}$ Dunn (in press).

i Vincent and Killingley (this volume).

$\mathrm{j}$ Pisias and Shackleton (this volume).

$k$ Dunn (1982).

lier), a proper study of regional productivity changes with time, latitude, and longitude would require considerably more extensive HPC transects (east-west, north-south).

To conclude, we focus on the interval of about 8 to $9 \mathrm{Ma}$ (on the Berggren et al. [in press] time scale; about 9 to $10 \mathrm{Ma}$ on earlier scales) to outline a possible path toward a future paleoceanographic synthesis involving the four elements just iterated. The central basin of the central equatorial Pacific, which lies roughly 30 to $40^{\circ}$ west of the Leg 85 drill sites, and thus well outside the high-productivity belt, is an area where accumulation of sediments during the Neogene has generally proceeded below the CCD. Sediment accumulation rates are therefore an order or more slower in this basin (Theyer and Hammond, 1974) than in the region of Leg 85 that lies to the east. The sediments of the central basin are composed primarily of clays, with varying percentages of biogenic silica. Current work on piston cores from the area (W. Dorn, dissertation research under F. T.) demonstrates that many of the NH events (Barron and Keller, 1982) are nevertheless developed there as well. More specifically, the middle to upper Miocene piston core M7017 (Fig. 9) contains magnetostratigraphic, biostratigraphic, mineralogic, and textural evidence (in X-ray photographs) of a major hiatus that correlates with NH5 of Keller and Barron (1983). (Note that the time scalethat is, the correlation of marine magnetic anomalies with the "absolute" time scale of this particular late Miocene interval-is currently under discussion and revision [Barron et al., this volume; Berggren et al., in press]. The revision means that hiatuses $\mathrm{NH} 4$ and NH5, and associated paleoceanographic events, previously separated by about 1.5 m.y., are now separated in time by less than $1 \mathrm{~m} . \mathrm{y}$.) NH5 was first described (Barron and Keller, 1982) in sequences of the northeastern Pacific rim, in a depositional environment vastly different from that of Core M70-17.

At Sites 573 to 575 , about $30^{\circ}$ to the east of Core M70-17, and in a depositional environment above the CCD dominated by carbonate, there is also evidence for the presence of hiatus NH5 (Fig. 9; also Weinreich and Theyer, this volume; Barron et al., this volume). At Site 572 , farther to the east (Fig. 1), and under a zone of extreme surficial productivity, this hiatus is not developed, but Bukry (this volume) records a strong nannofloral cooling event at 8 to $9 \mathrm{Ma}$ at this site. This same stratigraphic interval corresponds (at Sites 572 to 575 and elsewhere; Table 2) also to a major drop in $\mathrm{CaCO}_{3}$ percentages (site chapters, this volume). Mayer et al. (this volume) have shown that such a decrease in $\mathrm{CaCO}_{3}$ causes an acoustic impedance change which appears as a strong reflector during seismic profiling (Table 2). Thus, pending resolution of current time-scale quandaries, it is likely that the "Purple" reflector of Mayer et al. (this volume), defined at Site 574, is the seismic expression of NH5 in the carbonate-rich equatorial Pacific (although it may also be correlatable with NH4). On a global scale, the interval between 8 and $9 \mathrm{Ma}$ is generally accepted (Barron and Keller, 1982) to be marked by a dramatic drop in sea level (Vail and Hardenbol, 1979), and by a significant shift to heavier values, indicating cooling, in the oxygen-isotope curve derived from benthic foraminifers (Woodruff et al., 1981).

Evaluation of these diverse lines of evidence requires a more precise stratigraphic linking. Close examination may well reveal that several more or less independent events occurred during this interval. Nevertheless, there is now no doubt that globally drastic cooling, coupled with a strong regression, and significant drops in carbonate deposition, characterized this interval between 8 


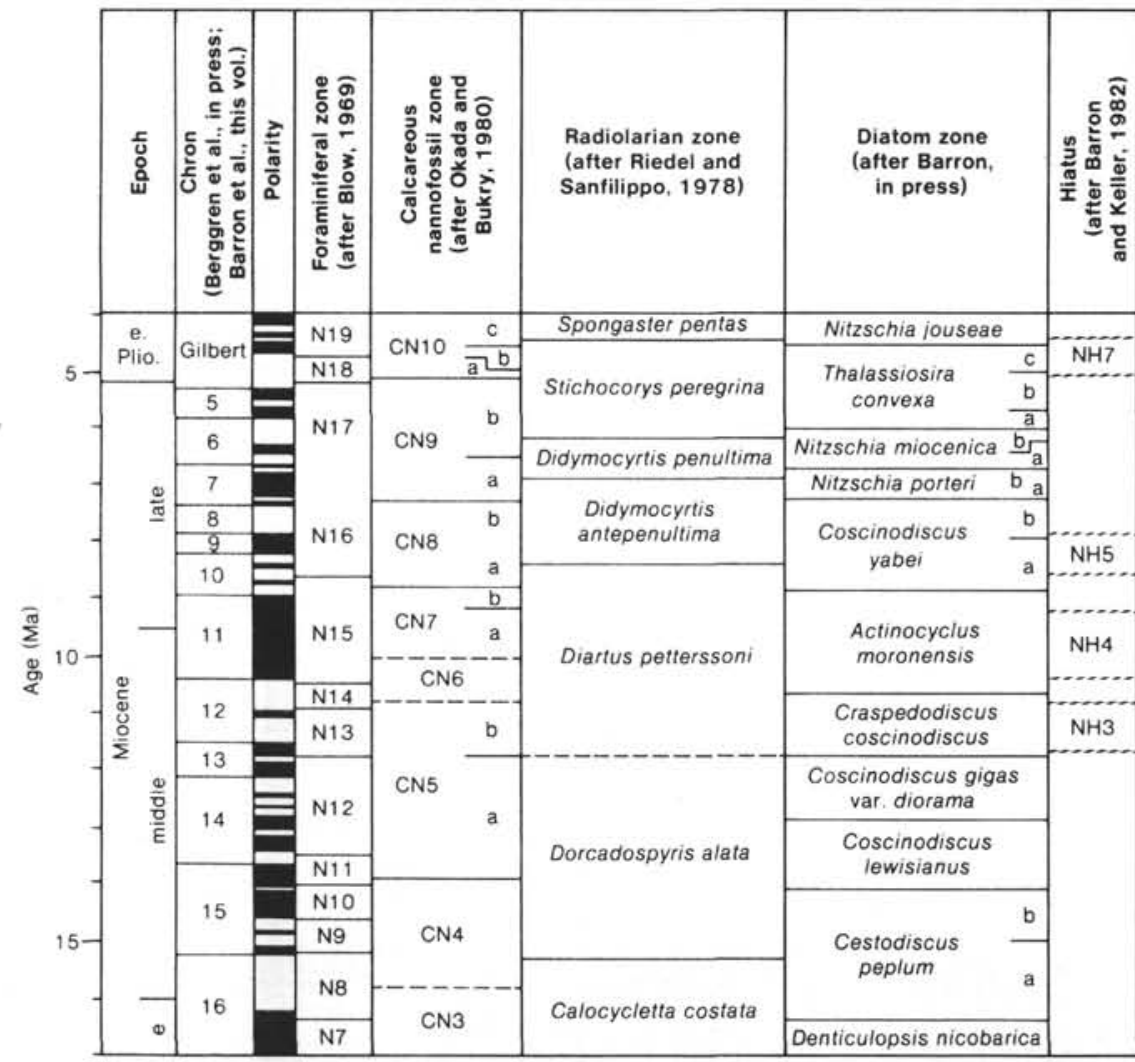

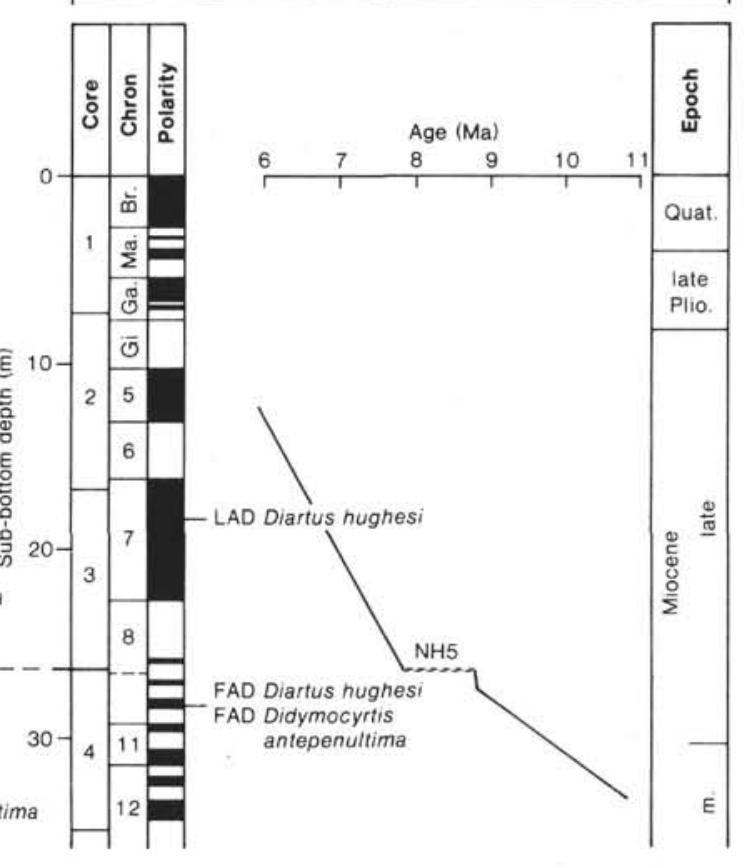

Figure 9. Correlation between (A) the hiatus stratigraphy of Barron and Keller (1982), (B) HIG Piston Core M70-17 from the Pacific's central basin, (C) the "Purple" reflector, and (D) DSDP Site 575 (Hole 575) in the east central equatorial Pacific. Magnetostratigraphic and radiolarian data of Hole 575 (D; Weinreich and Theyer, this volume; Barron et al., this volume) indicate a correlative hiatus. The presence of the hiatus at Site 575 is further supported by the planktonic foraminiferal (Saito, this volume) and diatom (not shown; Barron et al., this volume) stratigraphies. Although separated by more than $26^{\circ}$ of longitude, and situated in different depositional environments, the hiatus at both locations spans the entire Chron 9 interval and correlates with NH5. The Purple reflector (C) of Mayer et al. (this volume) also appears to correlate with NH5. 
and $9 \mathrm{Ma}$. What triggered them-and how these changes specifically interacted to cause hiatus NH5 (NH4?) in environments as dissimilar as the Pacific central basin clays, the high-productivity deposits of the Leg 85 area, and the northeast Pacific rim-is at this time still open to speculation. We must continue to study such paleoceanographic phenomena in a variety of depositional environments and within a precise stratigraphic framework to elucidate their functioning.

\section{ACKNOWLEDGMENTS}

Our special thanks go to R. G. Douglas, J. D. Hays, and the JOIDES OPP, who led the "battle" for this leg. F. Theyer's research was supported by NSF grants OCE81-17997 and OCE85-04146. L. A. Mayer's work was supported in part by ONR contract N00014-82-K0625, and by the Natural Sciences and Engineering Council of Canada. E. Thomas's research was supported by NSF grant OCE83-10518.

\section{REFERENCES}

Anderson, R. N., and Sclater, J. G., 1972. Topography and evolution of the East Pacific Rise between $5^{\circ} \mathrm{S}$ and $20^{\circ} \mathrm{N}$. Earth Planet. Sci. Lett., 14:433-441.

Arrhenius, G. O., 1952. Sediment cores from the East Pacific. Swedish Deep-Sea Exped. Rept. 1947-48, 5(Pt. 3):189-201.

Austin, T. S., 1960. Oceanography of the east central equatorial Pacific as observed during Expedition Eastropic. U.S. Fishery Bull., $168(60): 257-282$.

Barron, J. A., in press. Miocene to Quaternary planktic diatom biostratigraphy. In Bolli, H. M., and Saunders, J. B. (Eds.), Biostratigraphy of Marine Plankton: Cambridge (Cambridge University Press).

Barron, J. A., and Keller, G., 1982. Widespread Miocene deep-sea hiatuses: Coincidence with periods of global cooling. Geology, 10: 577-581.

Barron, J. A., Keller, G., and Dunn, D. A., in press. A multiple microfossil biochronology for the Miocene. In Kennett, J. P. (Ed), Cenozoic Paleoceanography Synthesis (CENOP). Mem. Geol. Soc. Am.

Berger, W. H., 1973. Cenozoic sedimentation in the eastern tropical Pacific. Geol. Soc. Am. Bull., 84:1941-1954.

1982. Climate steps in ocean history-lessons from the Pleistocene. In Berger, W. H., Crowell, J. C., et al. (Eds.), Climate in Earth History, Studies in Geophysics: Washington (National Academy Press), pp. 43-54.

Berger, W. H., and von Rad, U., 1972. Cretaceous and Cenozoic sediments from the Atlantic Ocean. In Hayes, D. E., Pimm, A. C., et al., Init. Repts. DSDP, 14: Washington (U.S. Govt. Printing Office), 787-954.

Berger, W., and Winterer, E. L., 1974. Plate stratigraphy and the fluctuating carbonate line. In Hsü, K. J., and Jenkins, H. C. (Eds.), Pelagic Sediments on Land and Under the Sea. Int. Assoc. Sedimentol. Spec. Publ., 1:11-48.

Berggren, W. A., Kent, D. V., and Van Couvering, J. A., in press. Neogene geochronology and chronostratigraphy. In Snelling, N. J. (Ed.), Geochronology and the Geologic Time Scale. Spec. Pap. Geol. Soc. London.

Blow, W. H., 1969. Late middle Eocene to Recent planktonic foraminiferal biostratigraphy. First Int. Conf. Planktonic Microfossils $(\mathrm{Ge}-$ neva, 1967), pp. 199-421.

Bramlette, M. N., 1961. Pelagic sediments. In Sears, M. (Ed.), Oceanography: Washington, D. C. (Am. Assoc. Adv. Sci.), pp. 345-366.

Defant, A., 1961. Physical Oceanography (Vol. 1): New York (Pergamon Press).

Dunn, D. A., 1982. Miocene sediments of the equatorial Pacific Ocean: Carbonate stratigraphy and dissolution history [Ph.D. thesis]. University of Rhode Island.

, in press. Early to middle Miocene carbonate stratigraphy and correlations of Pacific DSDP sites. In Kennett, J. P. (Ed.), Cenozoic Paleoceanography Synthesis (CENOP). Mem. Geol. Soc. Am. 163.
Embley, R. W., and Johnson, D. A., 1980. Acoustic stratigraphy and biostratigraphy of Neogene carbonate horizons in the north equatorial Pacific. J. Geophys. Res., 85:5423-5437.

Ewing, J., Ewing, M., Aitken, T., and Ludwig, W. J., 1968. North Pacific sediment layers measured by seismic profiling. In Knopoff, L., Drake, C. L., and Hart, P. J. (Eds.), The Crust and Upper Mantle of the Pacific Area. Am. Geophys. Union Geophysical Monograph no. 12, pp. 147-186.

Francheteau, J., Harrison, C. G. A., Schlater, J. G., and Richards, M. L., 1970. Magnetization of Pacific seamounts: A preliminary polar wander curve for the northeastern Pacific. J. Geophys. Res., 75:2035-2061.

Hays, J. D., Saito, T., Opdyke, N. D., and Burckle, L. H., 1969. Pliocene-Pleistocene sediments of the equatorial Pacific: Their paleomagnetic, biostratigraphic and climatic record. Geol. Soc. Am. Bull., 80:1481-1514.

Hays, J. D., et al., 1972. An interpretation of the geologic history of the eastern equatorial Pacific from the drilling results of the Glomar Challenger, Leg 9. In Hays, J. D., et al., Init. Repts. DSDP, 9: Washington (U.S. Govt. Printing Office), 909-931.

Herron, E. M., 1972. Sea floor spreading and the Cenozoic history of the east-central Pacific. Geol. Soc. Am. Bull. 83:1671-1692.

Johnson, D. A., 1972. Ocean-floor erosion in the equatorial Pacific. Geol. Soc. Am. Bull., 83:3121-3144.

Keller, G., 1983. Paleoclimatic analyses of middle Eocene through Oligocene planktic foraminiferal faunas. Palaeogeogr., Palaeoclimatol., Palaeoecol., 43:73-94.

Keller, G., and Barron, J. A., 1983. Paleoceanographic implication of Miocene deep sea hiatuses. Geol. Soc. Am. Bull., 94:590-613.

Keller, G., Barron, J. A., and Burckle, L. H., 1982. Paleomagnetic, stable isotope, carbonate, and microfossil stratigraphies in upper Miocene sediments in the North Pacific Ocean. Mar. Micropaleontol., 7:327-357.

Kennett, J. P., 1983. Paleo-oceanography-global ocean evolution. Rev. Geophys. Space Phys., 21:1258-1274.

Koblentz-Mishke, O. J., Volkovinsky, V. V., and Kabanova, J. G., 1970. Plankton primary production of the world ocean. In Woosten, W. S. (Ed.), Scientific Exploration of the South Pacific: Washington (Nat. Acad. Sci.), pp. 183-193.

Lisitsin, A. P., 1970. Sedimentation and chemical considerations. In Wooster, W. S. (Ed.), Scientific Exploration of the South Pacific: Washington (Nat. Acad. Sci.), pp. 89-132.

Loutit, T., and Keigwin, L. R., Jr., 1982. Stable isotopic evidence for latest Miocene sea-level fall in the Mediterranean region. Nature, 300:163-166.

Mayer, L. A., 1979a. Deep-sea carbonates: Acoustic, physical and stratigraphic properties. J. Sedimentol. Petrol., 49(3):819-836. $1979 \mathrm{~b}$. The origin of fine scale acoustic stratigraphy in deepsea carbonates. J. Geophys. Res., 84(B11):6177-6184.

Moore, T. C., Jr., 1970. Abyssal hills in the central equatorial Pacific: Sedimentation and stratigraphy. Deep-Sea Res., 17:573-593.

Moore, T. C., Jr., van Andel, T. H., Sancetta, C., and Pisias, N., 1978. Cenozoic hiatuses in marine sediments. Micropaleontology, 24:113-138.

Murray, J., and Renard, A. F., 1891. Deep sea deposits: report of the scientific results of the HMS Challenger, 1873-1876: London (H.M.S.O.),

Okada, H., and Bukry, D., 1980. Supplementary modification and introduction of code numbers to the low-latitude coccolith biostratigraphic zonation (Bukry, 1973, 1975). Mar. Micropaleontol., 5: 321-325.

Peterson, M. N. A., 1966. Calcite rates of dissolution in a vertical profile in the central Pacific. Science, 154:1342-1544.

Prell, W. L., Gardner, J. V., et al., 1982. Init. Repts. DSDP, 68: Washington (U.S. Govt. Printing Office).

Reid, J. L., 1962. On the circulation, phosphate-phosphorus content and zooplankton volumes in the upper part of the Pacific Ocean. Limnol. Oceanogr., 7:287-306.

Riedel, W. R., and Funnell, B. M., 1964. Tertiary sediment cores and microfossils from the Pacific Ocean floor. Q. J. Geol. Soc. London, 120:305-368.

Riedel, W. R., and Sanfilippo, A., 1978. Stratigraphy and evolution of tropical Cenozoic radiolarians. Micropaleontology, 24(1):61-96. 
Saito, T., Burckle, L. H., and Hays, J. D., 1975. Late Miocene to Pleistocene biostratigraphy of equatorial Pacific sediments. In Saito, T., and Burckle, L. (Eds.), Late Neogene Epoch Boundaries: New York (Am. Mus. Nat. History), pp. 226-244.

Savin, S. M., Douglas, R. G., Keller, G., Killingley, J. S., Shaughnessy, L., et al.,1981. Miocene benthic foraminiferal isotope records: A synthesis. Mar. Micropaleontol., 6:423-450.

Schlanger, S. O., and Douglas, R. G., 1974. The pelagic ooze-chalklimestone transition and its implications for marine stratigraphy. In Hsü, K. J., and Jenkyns, H. C. (Eds.), Pelagic Sediments on Land and Under the Sea. Int. Assoc. Sedimentol. Spec. Publ., 1: 117-148.

Sclater, J. G., Anderson, R. N., and Bell, M. L., 1971. Elevation of ridges and evolution of the central eastern Pacific. J. Geophys. Res., 76:7888-7915.

Shackleton, N. J., and Opdyke, N. D., 1973. Oxygen isotope and paleomagnetic stratigraphy of equatorial Pacific core V28-238: Oxygen isotope temperatures and ice volume on 105-year and 106-year scale. Quat. Res., 3:39-55.

Theyer, F., and Hammond, S. R., 1974. Paleomagnetic polarity sequence and radiolarian zones, Brunhes to Epoch 20. Earth Planet. Sci. Lett., 22:307-319.

Theyer, F., Mato, C. Y., and Hammond, S. R., 1978. Paleomagnetic and geochronologic calibration of latest Oligocene to Pliocene ra- diolarian events, equatorial Pacific. Mar. Micropaleontol., 3: 377-395.

Vail, P. R., and Hardenbol, J., 1979. Sea-level changes during the Tertiary. Oceanus, 22:71-79.

Vail, P. R., Mitchum, R. M., Jr., and Thompson, S., 1977. Global cycles of relative changes of sea level. In Payton, C. E. (Ed.), Seismic Stratigraphy-Applications to Hydrocarbon Exploration. Am. Assoc. Petrol. Geol. Mem., 26:63-81.

van Andel, T. H., Heath, G. R., and Moore, T. C., Jr., 1975. Cenozoic history and paleoceanography of the central equatorial Pacific Ocean. Mem. Geol. Soc. Am., 143:1-134.

Vincent, E., 1981. Neogene carbonate stratigraphy of Hess Rise (central North Pacific) and paleoceanographic implications. In Thiede, J., Vallier, T. L., et al., Init. Repts. DSDP, 62: Washington (U.S. Govt. Printing Office), 571-606.

Winterer, E. L., 1973. Sedimentary facies and plate tectonics of the equatorial Pacific. Am. Assoc. Pet. Geol. Bull., 57:265-282.

Woodruff, F., Savin, S. M., and Douglas, R. G., 1981. Miocene stable isotope record: A detailed deep Pacific Ocean study and its paleoclimatic implications. Science, 212:665-668.

Date of Initial Receipt: 4 October 1984

Date of Acceptance: 1 March 1985 